\title{
Elastosis perforans serpiginosa and down syndrome: A case
}

\author{
Sibel Berksoy Hayta, Rukiye Güner, Melih Akyol, Sedat Özçelik
}

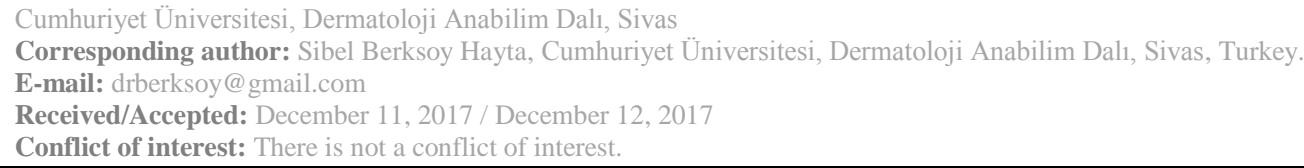

\section{Dear Editor}

Elastosis perforans serpiginosa (EPS) is rare disease characterized by hyperkeratotic papules, transepidermal elimination of abnormal elastic fibers and focal dermal elastosis. It takes place within the primary perforating dermatoses and may be seen associated with hereditary disorders of connective tissue, use of D-penicilamin, sistinuria and romatoid arthritis. Especially, Down syndrome may be a co-exsiting syndrome ${ }^{1}$. We present a case with elastosis perforans serpiginosa and Down syndrome.

A 26-year-old girl with Down syndrome who admitted to our policlinic complained rash and pruritus on her upper extremities since her childhood. She had no any other dermatologic or systemic disease. Dermatologic examination revealed hyperkeratotic papules and plaques on her forearms and right arcus mandibularis (Figure 1 $a, b, c)$. Histopathologic examination of the lesions showed that the findings of transepidermal elimination and the diagnosis was made as elastosis perforans serpiginosa (Figure 2 a,b; $3 a, b$ ). Previous treatments of the patient include only topical corticosteroids and emollients. Topikal imiquimod is recommended, but her parent did not accept this treatment. Therefore, proposing emollients, we decided to follow up the patient.

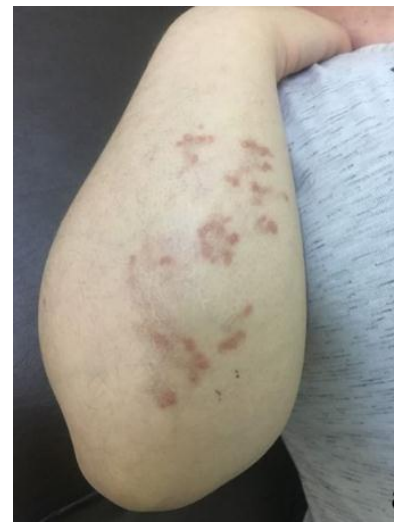

a

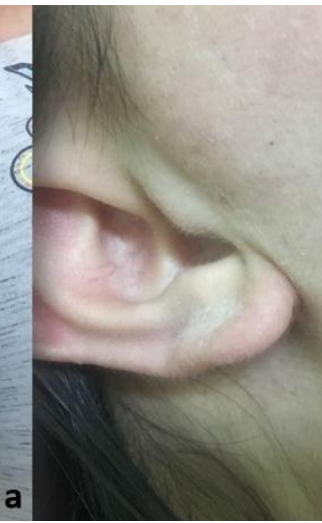

Figure 1 a,b,c: Clinical appearance of the case.

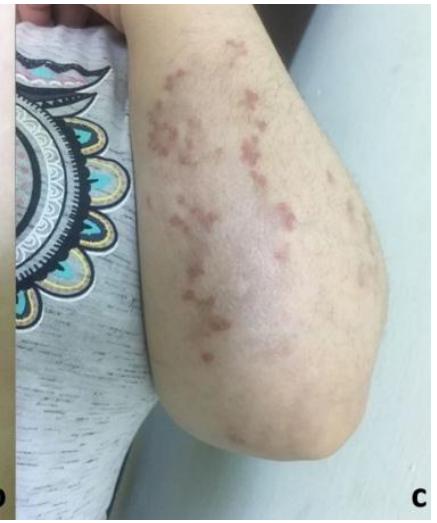

C 


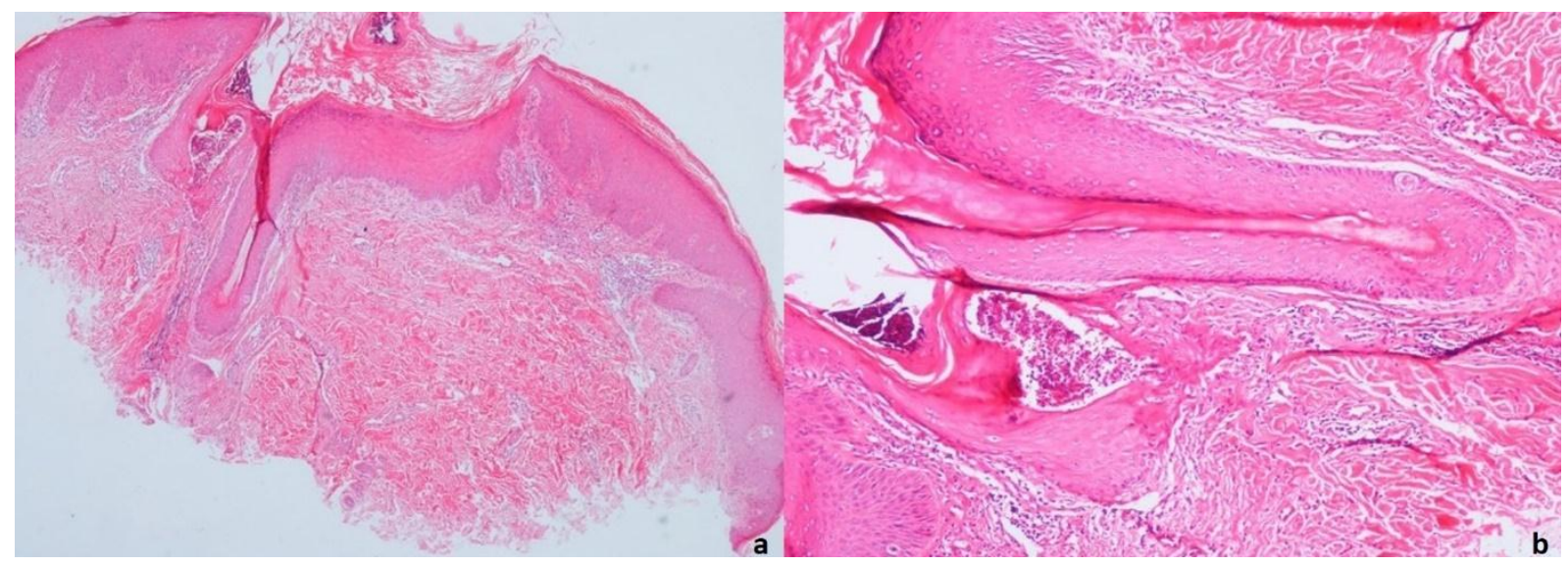

Figure 2 a,b: Transepidermal elimination (HE; a:x40, b:x100).
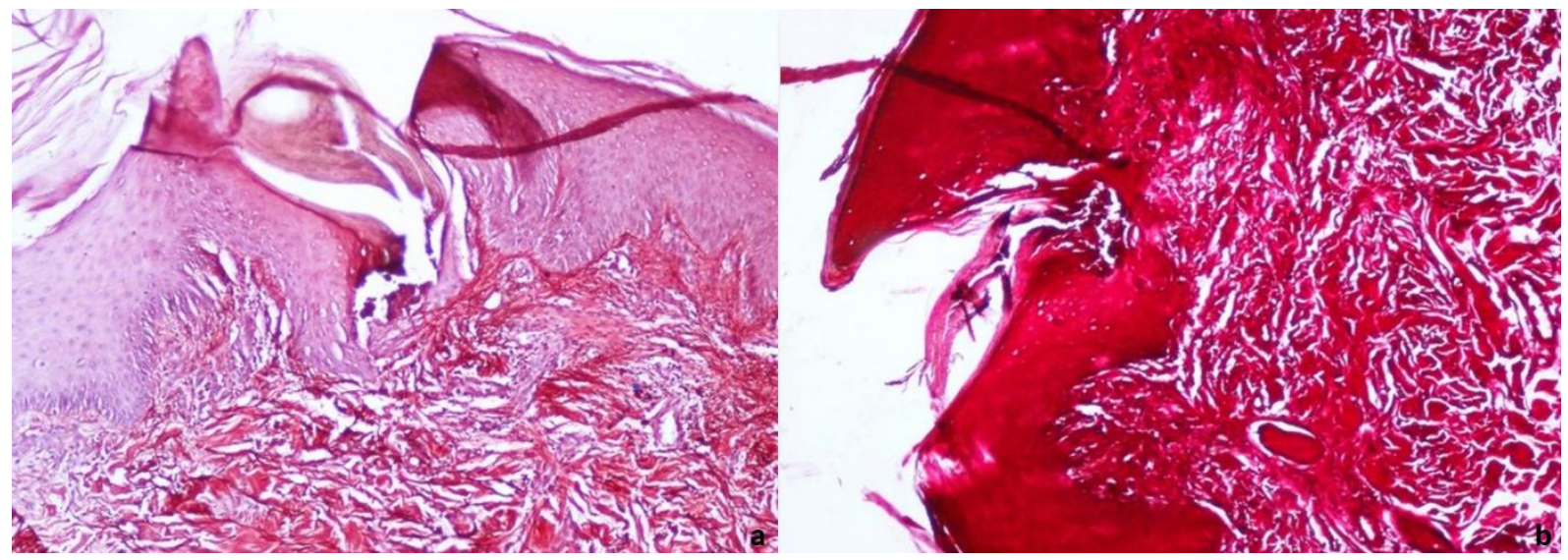

Figure 3 a,b: Abnormal elastic fibers (a:Orcein, x100, b:Verhoeff-van Gieson, × 100)

The etiology of EPS is unclear. Focal inflammation in the dermis cause the opening of the epidermal and follicular channels, allowing abnormal elastic fibers to pass out. In the epidermis around the transepidermal channels, interactions between elastin peptids and $67 \mathrm{kDa}$ elastin receptors are responsible in the pathogenesis of EPS ${ }^{2,3}$.

There are three clinical types of EPS:

1- Idiopathic

2- Reactive EPS associated with connective tissue disease: Down syndrom, EhlerDanlos syndrom, Ostegenesis imperfecta, Marfan syndrom, Rothmund-Thomson syndrom and acrogeria and other connectice tissue diseases.

3- Penicillamine induced EPS: Patiens with Wilson disease and cystinuria treated with penicillamine ${ }^{4}$.

Lesions are more common on the face, neck, trunk and upper extremities. Prognosis of EPS is benign.
Extracutaneous involvement is not expected ${ }^{3}$. In our case, the lesions were on the upper extremities and face unilaterally. Sometimes, spontaneous resolution may be seen, but it persist 5-6 years. The cases with Down syndrome may persist for longer (10 years). It is more common in males $(75 \%)^{2,3}$. In our case, the lesions had been appeared in childhood and showed exacerbations.

Histopathologic examination is the gold standart in the diagnosis of EPS. Characteristic histopathologic findings are the qualitative or quantitative changes of elastic fibers (increased and thickened fibers) and transepidermal elimination $2,5,6$.

Only $25 \%$ of the cases with EPS may be associated with any disease (Table 1). Approximately $1 \%$ of the cases with Down syndrome show the clinical findings of EPS ${ }^{1-3}$. Similar lesions have not been identified in the family of our case. 
Table 1. Diseases associated with EPS

\begin{tabular}{ll}
\hline Down's syndrome & Ehlers-Danlos syndrome \\
Marfans syndrome & Pseudoxanthoma elasticum \\
Acrogeria & Rothmund-Thomson syndrome \\
Osteogenesis imperfecta & Morphoea \\
Systemic sclerosis & Drug induced \\
\hline
\end{tabular}

The differential diagnosis of EPS include granuloma annulare, tinea corporis, annular sarcoidosis, cutaneous calcinosis and porokeratosis of Mibelli.

Treatment of EPS is difficult. Removing the keratin on the surface with cellophane tape, cryotherapy, elektrodesiccation, dermabrasion, topical corticosteroids, topical retinoidc, topical imiquimod, resurfacing with $\mathrm{CO} 2$ and flashlamp pulse dye lasers ve sistemic isotretinoin treatment ( $25 \mathrm{mg} /$ day) are the treatment options for EPS ${ }^{1,2,7,8}$. Imiquimod therapy was planned in our case, but the treatment was not accepted by the patient's parent and it was decided to be followed only with local emollients.

Our case is presented because of its rarity. It is important to know its etiological factors and associated diseases in the following of EPS.

\section{REFERENCES}

1- Lebwohl M. Acquired perforating disorders. In: Fitzpatrick's Dermatology in General Medicine, Wolf K, Goldsmith LA, Katz SI, Gilchrest BA, Paller AS, Leffell DJ (eds), seventh edition, McGraw Hill, New York, 2008; 564-7.
2- Pereira ACF, Baeta IGR, Junior SRC ve ark. Elastosis perforans serpiginosa in a patient with Down's syndrome. An Bras Dermatol 2010; 85: 691-4.

3- Mehta RK, Burrows NP, Rowland Payne CME ve ark. Elastosis perforans serpiginosa and associated disorders. Clin Exp Dermatol 2001; 26: 521-4.

4- Hernandez-Ruiz E, Garcia-Herrera A, Ferrando J. Scaly Erythematous Patches in a patient with Down syndrome. Actas Dermosifiliogr 2015; 106: 753-4.

5- Crotty G, Bell M, Estes SA ve ark. Cytologic features of elastosis perforans serpiginosa (EPS) associated with Down's syndrome. J Am Acad Dermatol 1983; 8: 255-6.

6- Mehregan AH. Elastosis perforans serpiginosa: a review of the literature and report of 11 cases. Arch Dermatol 1968; 97: 381-93.

7- Gregersen PA. Elastosis Perforans Serpiginosa in a patient with Down syndrome treated with imiquimod 5\% cream. Dermatology Reports 2010; 2: e15.

8- Kaufman AJ. Treatment of Elastosis Perforans Serpiginosa with the Flashlamp pulsed dye laser. Dermatol Surg 2000; 26: 1060-2. 